\title{
Construction of TVET M-Learning Model based on Student Learning Style
}

\author{
Azmi $S^{1}$ \\ Department of Skills Development \\ Ministry of Human Resources, \\ 62530 Putrajaya, Malaysia
}

\author{
Mat Noor S.F ${ }^{2}$, Mohamed $\mathrm{H}^{3}$ \\ Faculty of Information Science and Technology \\ Universiti Kebangsaan \\ 43600 Bangi, Selangor Malaysia
}

\begin{abstract}
Mobile learning or m-learning is emerging as the innovation of virtual learning that used mobile devices for teaching and learning which can be accessed readily at hand anywhere either in classroom or group. Whereas preliminary study showed that Technical and Vocational Education and Training (TVET) institution were still using the conventional learning, where the students were not getting much exposure at all towards m-learning. In fact, this research discussed about the development and validating the usability of TVET m-learning model based on the user requirements that categorized into three main aspects: devices, users and social. The research scope focused on TVET students as the target users. While, usercentered design (UCD) method has been used in this research through four phases which were analyzing the user requirements, designing model, developing prototype and evaluating usability. Based on the usability evaluation results showed that TVET m-learning model is acceptable and compatible as a guideline of m-learning development for the TVET students. This TVET m-learning model brings benefits in improving the quality of teaching and learning in TVET institutions especially the public training skills institutions to achieve the nation goals in order to become a successful developing country and produce skilled workers in the future as well.
\end{abstract}

Keywords-M-learning; technical and vocational education and training (TVET); user-centered design (UCD)

\section{INTRODUCTION}

Malaysia has been forged ahead to become a successful developing country in all kind of sectors with evolving of latest mobile technology. In order to be more successful in TVET sector, the innovation of mobile technologies is applied for the rising quality of teaching and learning. In particular, it helps in exposing the students more on m-learning and lifelong learning. The positive implications indirectly affect the TVET students in terms of careers, personalities and knowledge that strengthening them to be hired as well as adapting themselves in industrial work and environment [19], [21].

Based on previous studies, the implementation of $\mathrm{m}$ learning in learning process brought positive impacts to the students and teachers. For instance, maximizing the sharing and exchanging of information activities, the use of mobile learning regardless of time and place and ease the delivery of information in learning [1]. The students benefit from mlearning to get the full information and knowledge easily, can access the content anywhere they want to. This paper focused on the model of TVET m-learning to clearly show the development of functionality and features of the system that were obtained based on user requirements and used as the guideline of m-learning application development.

Conventional learning or traditional learning is a pioneer of learning process that involves teaching and learning process between the students and teachers in classroom. Beyond that, the most common role of teachers is to convey knowledge while the students are just following every actions and words at the same time [20]. This process normally caused by oneway communication. In parallel with the evolving of mobile devices, the transformation of learning process towards mobile devices from computer has changed and well known as mlearning. Brown [2] stated that there were two types of flexible learning that were face-to-face learning and longdistance learning. While long distance learning is categorized into two parts that are e-learning and long-distance learning paper-based. Meanwhile, m-learning and online learning are specifically classified in e-learning.

M-learning is one of innovation of e-learning that have learning features which are embedded in e-learning such as accessing the learning materials, tasks, quizzes, forum discussion, user messenger, calendar and current notice activities [3]. Advances of mobile devices as the medium of interaction in technology that provide a lot of features such as short messaging service (SMS) and multimedia, sending and receiving emails, and applications that have the combination of short messaging service (SMS) and multimedia elements such as sound, image, animation and video [4]. In fact, the advances in technologies help the efficiency of learning. According to Bogdanović et al. [5], the implementation of quiz evaluation using m-learning among the students who familiar with mobile devices proved that m-learning itself was more effective, improving the motivation and students' performances.

M-learning provides unlimited excessing online learning regardless of time and place, the students could easily bring the mobile devices anywhere [6]. Besides that, m-learning enables teaching and learning opportunities to new learners by giving them chances to use active learning process in selflearning context [7]. The comparisons between previous models of m-learning focused on three main aspects which were devices, users and social [8]. These comparisons 
absolutely helped in determining the additional requirements needed in developing the model of TVET m-learning.

Those requirements of physical, technical or functionality features in the devices were actually needed to be compatible with the users. However, from the perspective of the users, Abdullah et al. [9] and Irwan Mahazir et al. [10] stated that mastery learning and process of learning were synced with the user mental model in Vygotsky - ZPD and model of Rudric and Krulik problem solving. Therefore, the characteristics of learning could be as reference to define the tendency of users' learning styles towards the m-learning model. While, Sha et al. [11] was focusing on self-regulated learning where the users could control the learning activities that specified on goals and achievements. These characteristics were defined to be integral in m-learning as the activity control.

Hence, to design the model of TVET m-learning completely, there were additional requirements to be included in designing the model. For device aspect, the device specifications must be compatible with the users. While, for user aspect, instead of focusing on learning style only there were also defining on digital technology skills to ensure that the model developed was suitable with the users' skills. For social aspect, beside the activity control, data security system, user guide, m-learning activity, automatic notification, messaging and file storage which were additional features in the TVET m-learning model.

Besides, usability elements were also important in order to validate the model of m-learning. Chang et al. [12] and Park et al. [13] stated that the basic elements of usability such as usefulness, easy to use and user satisfaction as the factors of user's acceptance with the used of m-learning. These three elements act as main elements of usability to validate the TVET m-learning model. According to Nielsen [14], the usability of mean score which is 4.00 means that the usability of system or prototype is at the high level (adequately usable).

\section{METHOD}

This study used user-centered design (UCD) to develop mobile learning for TVET. UCD is commonly used in designing process of human computer interaction research [15], [23]. In general, this method is an approach of the whole development processes based upon an explicit activity that involve the users.

The best way to develop the system continuously is defining every activity that involved real users in the whole processes of development [16]. Thus, the system developer will focus more towards the users' requirements which is the main target to make the system easy to use and compatible to the user.

This method involved four phases as shown in Figure 1. These four phases are requirements analysis, conceptual design, implementation and usability evaluation.

\section{A. Phase I}

As stated in Figure 1, the first phase started with data collection to acquire the user requirements through questionnaire which consists of five sections referring to the previous studies as specifications of device, learning styles, digital technology skills, m-learning features and user perceptions towards mobile technology.

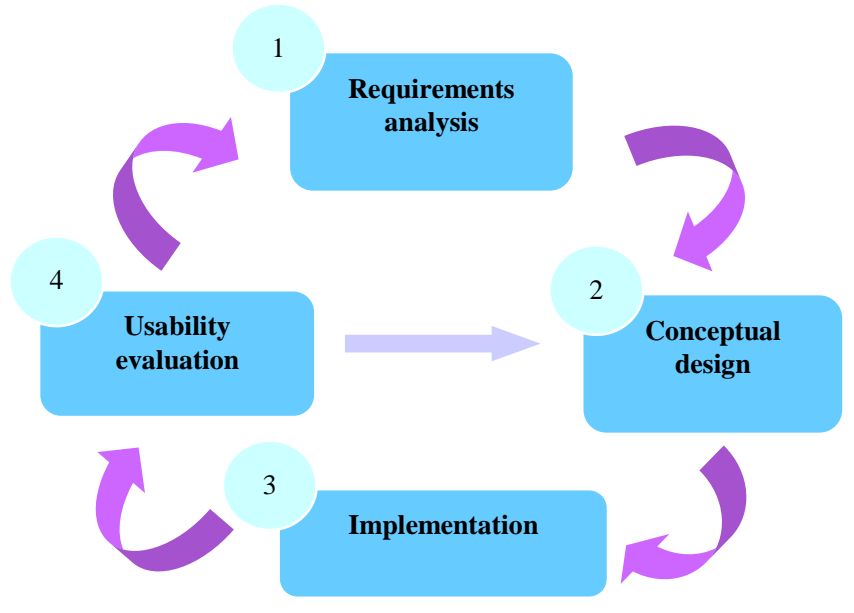

Fig. 1. Process of the user-Centered Design (UCD) Method.

\section{B. Phase II}

The second phase was designing the TVET m-learning model by referring to the data that obtained from the first phase. Designing the model involved three aspects which were device, user and social. Regarding the device aspect, the specifications of device used by the users are defined. Meanwhile, the user aspect defined the user's learning style and digital technology skills. Social aspect defined the features of m-learning. As a result, throughout this phase the TVET m-learning model was developed. So as to validate the model, prototype of mobile learning was developed.

\section{Phase III}

The third phase showed the development of prototype through two phases which were low-fidelity and high-fidelity prototype. The low-fidelity prototype was developed using the application software of Prototyping on Paper (POP) which the functions provided were the same as manual sketching in storyboard. While the high-fidelity prototype was developed using Android Studio software and developed based on data analysis of low-fidelity prototype through cognitive walkthrough method.

\section{Phase IV}

The last fourth phase was evaluating the usability of TVET m-learning prototype to test on the users in determining the element of usefulness, satisfaction, easy to use and learnability. The elements of usefulness consisted the useful of prototype towards users, activities provided were easy to complete, more effective and productive activities, activities can be done as expected and save time while activities were conducted. The element of satisfaction consisted of smoothness while using the system, good functionality of the system, entertaining and impressive system. In addition, the elements that were easy to use consisted of items where it can be used easily in the learning activities, user-friendly system, required fewest steps to accomplish activities, flexible interaction, clear instruction and guide, consistency, easy to recover the mistakes and successfully used by the users. While 
the element of learnability consisted of fastest way of learning on how to use the system, easy to learn the system, easy to remember on how to operate the system, quickly become skillful to use the system and not complicated to learn the user guide. These four elements of usability could be measured by using Lund [17] questionnaire on measurement of Likert Scale.

In order to evaluate the prototype specifically, there were two types of techniques used. The combination of observation and questionnaires techniques were used to measure the usability of the prototype. There were five steps in the usability evaluation. The first one was the evaluation of preparation by providing the experiment room and few tools such as video camera, mobile devices, note book, questionnaire instruments and the list of tasks in learning activities. This evaluation was done individually so that the researcher could focus on observing the users in every detail of activities during testing.

Before the evaluation process started, the researcher briefly explained about the evaluation. Next, user will follow the task list of activities in using m-learning while the researcher will observe and note-down every single action in case the activities could not be performed correctly. These activities and users' actions were recorded using video camera and at the same time those actions that had been done in the device were also recorded by using Mobizen application. The video recording was used as a backup of previous testing activities as a reference to researcher. After the learning activities using the TVET m-learning prototype done, the user was given the usability questionnaire to fill in.

The results of the usability testing were obtained by analysing using t-test which is used to validate the TVET mlearning model. These phases were summarized as shown in Figure 2.

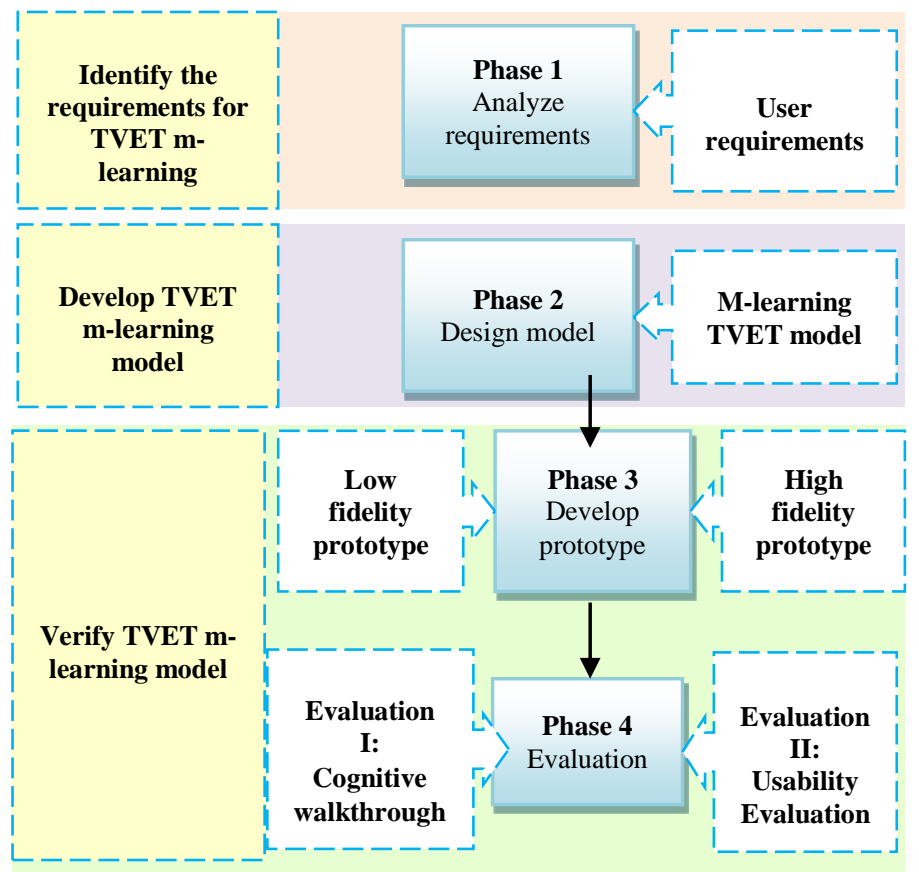

Fig. 2. User-Centered Design Method.

\section{RESULT AND DISCUSSION}

The TVET m-learning model was developed based on the analysis of user requirements which was focusing on three main aspects of m-learning: device, user and social. While the categories formation of the model was specified as device specifications, learning style, digital technology skills and mlearning features.

\section{A. TVET M-Learning Model}

The specifications of device were divided into four parts that were device, platform, features and functionality. Based on the user requirement, the device used was smartphone using the Android platform. In addition, the features in the device such as internet, 3G service and memory card are used for m-learning. The device also has the function of reading and opening digital files.

On the other hand, learning styles of TVET students were identified in the first dimension and third dimension of Felder and Silverman learning style [18]. The first dimension is about on how to process the information using the system. The learning style of this dimension was divided into two styles which were active and reflective. TVET students tend to be on active learning where they focused more on learning within groups rather than reflective or individual learning. Hence, the feature that adapted in TVET m-learning was learning within group instead of the individual learning. Meanwhile, third dimension refers to the tendency of students in memorizing so that they would be easy to use m-learning. Learning styles of this dimension were divided into visual and verbal. The tendency of TVET students on memorizing was easy in the form of visual rather than verbal. Therefore, the interface design of m-learning should be more graphically or icon used that can attract the TVET students' attention compared with to the interface design with text provided only.

Digital technology skills are the basic requirements for users to operate the system. With the level of skills, the developed system should be convenient for the users to operate. Therefore, the level of digital technology skills of TVET students were towards more on operating devices, social and mobile used which means they have the basic skills to operate the system well.

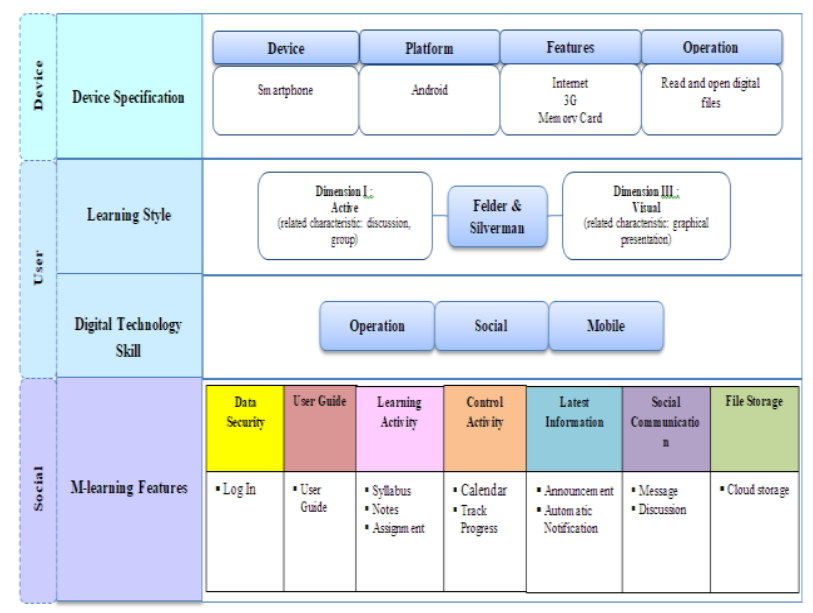

Fig. 3. TVET M-Learning Model. 
By referring to the analysis of user requirements obtained, the features of TVET m-learning were identified by categorizing them in data security, user guide, learning activity, activity control, latest information, social communication and files storage. These features were embedded in the prototype development.

The category of data security, the students needed to log in the system for assuring the safety of data and information. While the user guide was provided to ease the users and act as a guideline on how to use TVET m-learning. Besides, the category of learning activities including the basic activities that used by the students daily such as accessing the syllabus, notes and tasks from the system.

As shown in Figure 3, TVET m-learning model was developed based on the analysis of user requirements. By using this model, the low-fidelity and high-fidelity prototype were developed. These prototypes will be evaluated through cognitive walkthrough and usability evaluation to validate the TVET m-learning model for TVET students.

Students could control the activities by adding reminders in the calendar and tracking their activities progress. The students would also be receiving the latest information which will be announced by the teacher and automatically notified them in the m-learning system. So that, the students were always be ready by any cause when receiving information and doing the learning activity. If the students needed help from the teachers or friends, they could use the m-learning messaging service to communicate individually or among group. For digital files storage, memory card is the basic requirement for the mobile device. Thus, students should not be worried with the limited size of memory card because the TVET m-learning could link directly to the cloud storage throughout the learning activities.

\section{B. TVET M-Learning Usability}

In usability evaluation, there were 30 students were chosen from Multimedia Software Technology from ILP Kuala Langat to evaluate the TVET m-learning prototype. The questionnaires were given to the students in determining four usability elements which were system usefulness, easy to use, learnability and user satisfaction. The results of the analysis were shown in Table 1. Overall, average of the mean score for each element through bar chart was shown in Figure 4.

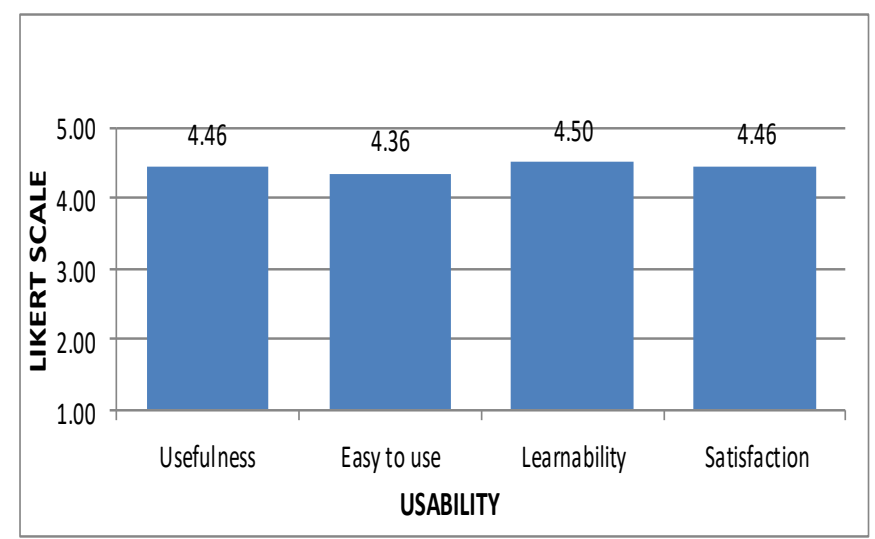

Fig. 4. Mean Score of TVET M-Learning Prototype Usability.
TABLE I. Usability Evaluation of TVET M-LEARNING PROtotype

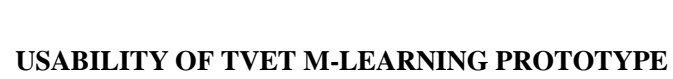

\begin{tabular}{|c|c|c|c|c|c|c|c|}
\hline \multicolumn{2}{|c|}{ Usefulness } & \multicolumn{2}{|c|}{ Easy to use } & \multicolumn{2}{|c|}{ Learnability } & \multicolumn{2}{|c|}{ Satisfaction } \\
\hline $\begin{array}{l}\text { Ite } \\
m\end{array}$ & $\begin{array}{l}\text { Mean } \\
\text { Score }\end{array}$ & $\begin{array}{l}\text { Ite } \\
m\end{array}$ & $\begin{array}{l}\text { Mean } \\
\text { Score }\end{array}$ & $\begin{array}{l}\text { Ite } \\
m\end{array}$ & $\begin{array}{l}\text { Mean } \\
\text { Score }\end{array}$ & $\begin{array}{l}\text { Ite } \\
m\end{array}$ & $\begin{array}{l}\text { Mean } \\
\text { Score }\end{array}$ \\
\hline $\mathrm{S} 1$ & 4.43 & S8 & 4.53 & S16 & 4.63 & S23 & 4.37 \\
\hline $\mathrm{S} 2$ & 4.57 & S9 & 4.33 & S17 & 4.57 & S24 & 4.43 \\
\hline $\mathrm{S} 3$ & 4.40 & $\mathrm{~S} 10$ & 4.27 & $\mathrm{~S} 18$ & 4.50 & S25 & 4.50 \\
\hline $\mathrm{S} 4$ & 4.30 & S11 & 4.40 & S19 & 4.40 & S26 & 4.23 \\
\hline S5 & 4.33 & $\mathrm{~S} 12$ & 4.47 & $\mathrm{~S} 20$ & 4.43 & S27 & 4.53 \\
\hline S6 & 4.57 & $\mathrm{~S} 13$ & 4.30 & $\mathrm{~S} 21$ & 4.47 & S28 & 4.60 \\
\hline \multirow[t]{2}{*}{ S7 } & 4.60 & S14 & 4.23 & $\mathrm{~S} 22$ & 4.53 & S29 & 4.57 \\
\hline & & S15 & 4.37 & & & & \\
\hline $\begin{array}{l}\text { Me } \\
\text { an }\end{array}$ & 4.46 & $\begin{array}{l}\text { Me } \\
\text { an }\end{array}$ & 4.36 & $\begin{array}{l}\text { Me } \\
\text { an }\end{array}$ & 4.50 & $\begin{array}{l}\text { Me } \\
\text { an }\end{array}$ & 4.46 \\
\hline
\end{tabular}

The mean scores of usefulness, easy to use, learnability and satisfaction were $4.46,4.36,4.50$ and 4.46 respectively. These values showed that the TVET m-learning were adequately usable and compatible to the users.

\section{CONCLUSIONS}

This study achieved the objectives by developing and validating of TVET m-learning model. Based on the data of usability evaluation showed that the mean score values of usability elements were at the high level which means that the TVET m-learning is adequately usable and compatible to TVET students in teaching and learning process.

The main contributions in this study were divided into two fields: m-learning and TVET. The first field is m-learning where, the study developed the model which, involving the users from the beginning of the development process and until the final phase of validating the model. Therefore, the details of user requirements have been obtained as the main focus in developing TVET m-learning model. The usability of TVET m-learning was highly effective based on the usability elements observed such as usefulness, user satisfaction, ease of use and learnability.

This study also contributes in TVET learning style where TVET m-learning model will be a guideline for the system developer in designing m-learning specifically for TVET students. With the features offered in m-learning will provide further improvements in teaching and learning, therefore bringing the excellence to TVET institutions. 


\section{ACKNOWLEDGMENT}

This study was supported by the Grant of GUP-2016-004, Faculty of Information Science and Technology, Universiti Kebangsaan Malaysia.

\section{REFERENCES}

[1] Hwang, G.-J., \& Wu, P.-H., "Applications, impacts and trends of mobile technology-enhanced learning: A Review of 2008-2012 publications in selected SSCI journals," International Journal of Mobile Learning and Organisation, 8(2), 83-95, https://doi.org/10.1504/IJMLO.2014.062346, 2014.

[2] Brown, T.H., "Towards a model for M-Learning in Africa," International Journal on E-Learning, 4(3), 299-315, 2005.

[3] Kumar, S., Gankotiya, A.K., \& Dutta, K., "A comparative study of moodle with other e-learning systems," ICECT $2011-20113^{\text {rd }}$ International Conference on Electronics Computer Technology, 5, 414418, https://doi.org/10.1109/ICECTECH.2011.5942032, 2011.

[4] Rashid, Z. A., Kadiman, S., Zulkifli, Z., Selamat, J., Hisyam, M., \& Hashim, M., "Review of Web-Based Learning in TVET: History, Advantages and Disadvantages. International Journal of Vocational Education and Training Reseaarch," 2(211), 7-17, https://doi.org/10.11648/j.ijvetr.20160202.11, 2016.

[5] Bogdanović, Z., Barać, D., Jovanić, B., Popović, S., \& Radenković, B., "Evaluation of mobile assessment in a learning management system. British Journal of Educational Technology," 45(2), 231-244, https://doi.org/10.1111/bjet.12015, 2014.

[6] Ally, M., \& Prieto-Blázquez, J., "What is the future of mobile learning in education?" RUSC, Universities and Knowledge Society Journal, 11(1), 142, https://doi.org/10.7238/rusc.v11i1.2033, 2014.

[7] Cochrane, T., \& Antonczak, L., "Implementing a Mobile Social Media Framework for Designing Creative Pedagogies," Soc. Sci,3 (SEPTEMBER 2014), 359-377, https://doi.org/10.3390/socsci3030359, 2014.

[8] Koole, M. L., “A model for framing mobile learning. Mobile Learning: Transforming the Delivery of Education and Training," 39, 2009.

[9] Abdullah, M. R. T. L., Hussin, Z., Asra, \& Zakaria, A. R., "MLearning scaffolding model for undergraduate English language learning: Bridging formal and informal learning," Turkish Online Journal of Educational Technology, 12(2), 217-233, 2013.

[10] Irwan Mahazir, I., Norazah, M. N., Din, R., Abdul Rahim, A. A., \& Che' Rus, R., "Design and Development Performance-based into Mobile Learning for TVET," Procedia - Social and Behavioral Sciences, 174 (2015), 1764-1770, https://doi.org/10.1016/j.sbspro.2015.01.835, 2015.
[11] Sha, L., Looi, C. K., Chen, W., \& Zhang, B. H., "Understanding mobile learning from the perspective of self-regulated learning. Journal of Computer Assisted Learning," 28(4), 366-378, https://doi.org/10.1111/j.1365-2729.2011.00461.x, 2012.

[12] Chang, C.-C., Yan, C.-F., \& Tseng, J.-S., "Perceived convenience in an extended technology acceptance model: Mobile technology and English learning for college students," Australasian Journal of Educational Technology, 28(5), 809-826, https://doi.org/10.14742/ajet.v28i5.818, 2012.

[13] Park, S. Y., Nam, M.-W., \& Cha, S.-B., 'University students' behavioral intention to use mobile learning: Evaluating the technology acceptance model," British Journal of Educational Technology, 43(4), 592-605, https://doi.org/10.1111/j.1467-8535.2011.01229.x, 2012.

[14] Nielsen, J., "Usability Engineering. Morgan Kaufman Pietquin O and Beaufort R," 1 st Edition. Academic Press, 1993.

[15] Ritter, F. E., Baxter, G. D., \& Churchill, E. F., "Foundations for Designing User-Centered Systems," London: Springer London, https://doi.org/10.1007/978-1-4471-5134-0, 2014.

[16] Preece, J., Sharp, H., \& Rogers, Y., "Interaction Design: Beyond Human-Computer Interaction (4th ed.)," United Kingdom: Wiley, 2015.

[17] Lund, A. M., "Measuring usability with the USE questionnaire," Usability Interface, 8(2), 3-6, 2001.

[18] Graf, S., Viola S., R., Lea, T., \& Kinshuk., "In Depth Analysis of the Felder-Silverman Learning Style Dimensions," Reseach on Technology in Education, 40(1), 79-93, 2007.

[19] Rasul, M. S., Hilmi, Z., Ashari, M., Azman, N., Amnah, R., \& Rauf, A., "Transforming TVET in Malaysia: Harmonizing the Governance Structure in a Multiple Stakeholder Setting," TVET-Online.Asia, (4), 1$13,2015$.

[20] Hanimastura, H., Hairulliza, M. J., \& Tengku Siti Meriam, T. W., "Success Factors for Knowledge Sharing Among Tvet Instructors," Journal of Theoretical and Applied Information Technology, 85(1), 1220, 2016.

[21] Mat Yaacob, N., \& Hussin, M., "Pendidikan Dan Latihan Teknik dan Vokasional (TVET) Dalam Konteks Memacu Pertumbuhan Ekonomi Malaysia," Proceeding International Conference On Global Education $V$, pp. 1147-1159, 2017.

[22] Sohimi, N.E, Affandi, H.M, Fadzil, H., \& Mohd Sattar, R., "Exploring The Malaysian Qlassic Practicality," Proceedings 4th International Conference on Vocational Education and Training (ICVET), 79, 16-23, 2016.

[23] Wook, T. S. M. T., Mohamed, H., Judi, H. M., \& Ashaari, N. S., "Applying cognitive walkthrough to evaluate the design of SPIN interface," Journal of Convergence Information Technology, 7(4), 106115. https://doi.org/10.4156/jcit.vol7.issue4.13, 2012. 